\title{
IMPLEMENTASI JARINGAN SYARAF TIRUAN UNTUK MENGIDENTIFIKASI POLA DESAIN PRODUK BERDASARKAN PREFERENSI PELANGGAN MENGGUNAKAN KANSEI ENGINEERING SYSTEM
}

\author{
Ibnu Mastur, Lumenta Hadi \\ Jurusan Teknik Industri, Fakultas Teknologi Industri, Universitas Islam Indonesia \\ Jl. Kaliurang Km. 14,5 Yogyakarta 55501 \\ Telp. (0274) 895287, Faks. (0274) 895007 ext. 148
}

\begin{abstract}
Kansei Engineering System (KES) is of technologies in ergonomics that support human-centered design. In Japanese, Kansei means customers' taste to a certain product. The research aims to apply KES Type II (a more recent development of KES)with artificial neural network (back propagation model) and traingdx learning algorithm to identify product design that fits best with customers' taste/preferences. The model developed is able to generate a design for steering wheel with various atributes; namely shape of button, number of spokes, material of spokes, texture of grip, style of grip, and color. These atributes are results from 16 pairs of Kansei words which is reduced into five main factors; namely aestethics, emotional evaluation, color, texture, and product reliability.
\end{abstract}

Keywords: Kansei Engineering System, artificial neural networks, back-propagation, customers' preferences.

\section{PENDAHULUAN}

\subsection{Latar Belakang}

Dalam mendesain suatu produk yang sangat penting untuk diperhatikan adalah suatu desain yang berpusat pada manusia pemakainya atau human centered design. Hal tersebut dimaksudkan agar setiap desain produk baik secara fungsi, teknologi, estetis maupun secara ergonomis sesuai dengan kebutuhan pemakainya [6].

Seiring dengan perkembangan teknologi, tingginya permintaan dan selera konsumen membuat strategi manufaktur saat ini mulai mangalami pergeseran dari konsep keluaran produksi (product out concept) menjadi strategi konsep masukan pasar (market in concept) yang berhubungan dengan produk baru. Strategi ini menganut prinsip produksi berdasarkan pada preferensi dan kecocokan pelanggan atau selera pelanggan terhadap suatu produk. Oleh karena itu strategi produksi berdasarkan pemenuhan kebutuhan pelanggan akan dapat menghasilkan keuntungan besar bagi perusahaan [4].

Rakayasa Kansei atau Kansei Engineering merupakan suatu teknologi dalam bidang Ergonomika yang berorientasi pada pelanggan untuk pengembangan produk. Kansei dalam bahasa Jepang dapat diartikan sebagai penterjemahan dari perasaan atau selera pelanggan terhadap suatu produk. Dalam konsep Kansei 
Engineering barang atau produk baru dibuat berdasarkan pada perasaan dan permintaan pelanggan [3].

Dalam mengembangkan sistematika kerangka kerja dari teknologi ini dipergunakan sistem terkomputerisasi dengan sistem pakar untuk menstransfer perasaan pelanggan dan citra ke dalam rancangan rinci. Dalam hal ini Jaringan Syaraf Tiruan dapat dipergunakan untuk membangun basis data yang terkait dengan sistem inferensi terkomputerisasi.

\subsection{Tujuan Penelitian}

1. Memahami citra atau perasaan pelanggan terhadap suatu produk melalui pendekatan ergonomis dan psikologis.

2. Mengidentifikasi karakteristik-karakteristik desain dari kansei pelanggan

3. Membangun Kansei Engineering System dengan Jaringan Syaraf Tiruan sebagai sistem inferensi terkomputerisasi.

\section{DASAR TEORI}

\subsection{Ergonomi}

Ergonomi berasal dari kata Yunani, yaitu ergon yang berarti kerja dan nomos yang berarti hukum atau aturan dan dapat didefinisikan sebagai studi tentang aspek-aspek manusia dalam lingkungan kerjanya yang ditinjau secara anatomi, fisiologi, psikologi, engineering, manajemen, dan desain/perancangan [6]. Ergonomi menjadi suatu aplikasi informasi ilmiah tentang manusia (metode ilmiah untuk memperoleh suatu informasi) untuk permasalahan desain (Pheasant, 1988).

Lebih lanjut, suatu desain produk disebut ergonomis apabila secara antropometris, faal, biomekanik dan psikologis kompatibel dengan manusia pemakainya. Di dalam mendesain suatu produk maka harus berorientasi pada production friendly, distribution friendly, installation friendly, operation friendly, dan maintenance friendly. Di samping hal-hal tersebut di atas di dalam mendesain suatu produk yang sangat penting untuk diperhatikan adalah suatu desain yang berpusat pada manusia dan pemakainya atau human centered design [6]. Hal tersebut dimaksudkan agar setiap desain produk baik secara fungsi, teknisteknologis, ekonomis, estetis, meupun secara ergonomis sesuai dengan kebutuhan pemakainya.

Dengan memperhatikan hal-hal tersebut maka penelitian dan pengembangan ergonomi akan memerlukan dukungan berbagai disiplin keilmuan seperti psikologi, antropologi, faal/anatomi dan (engineering)/steknologi [8].

\subsection{Kansei Engineering}

Kansei Engineering adalah teknologi yang menterjemahkan perasaan dan citra (image) pelanggan tentang suatu produk kedalam elemen-elemen desain atau dengan bahasa lain adalah teknologi yang berorientasi pada pelanggan untuk pengembangan produk dengan berbasis pada ergonomika dan ilmu komputer [3]. 


\begin{tabular}{|c|c|c|}
\hline $\begin{array}{c}\text { Kansei } \\
\text { atau } \\
\text { Selera psikologi }\end{array}$ & $\begin{array}{c}\text { Kansei } \\
\text { Engineering } \\
\text { System (KES) }\end{array}$ & $\begin{array}{c}\text { Elemen-Elemen } \\
\text { Desain } \\
\text { Produk }\end{array}$ \\
\hline
\end{tabular}

Gambar 1. Proses dari Sistem Rekayasa Kansei [3]

Pada perkembangannya teknologi Rekayasa Kansei ini mempunyai 3 macam model, antara lain:

1. Kansei Enginering Type I (Klasifikasi Kategori)

Klasifikasi kategori adalah suatu metode dimana kategori kansei dari produk diuraikan dalam pohon struktur untuk mendapat rancangan rinci.

2. Kansei Engineering Type II (Sistem Komputer)

Adalah sistem terkomputerisasi dengan sistem pakar untuk menstransfer perasaan dan citra pelanggan ke dalam rancangan rinci.

3. Kansei Engineering Type III (Pemodelan Rekayasa Kansei)

Dalam pemodelan kansei ini, suatu model matematis dibangun dalam basis peraturan yang rumit untuk mencapai keluaran ergonomis dari kata-kata kansei.

\subsection{Jaringan Syaraf Tiruan}

Merupakan salah satu representasi buatan dari otak manusia yang selalu mencoba untuk mensimulasikan proses pembelajaran pada otak manusia tersebut. Istilah buatan disini digunakan karena jaringan syaraf ini diimplementasikan dengan menggunakan program komputer yang mampu menyelesaikan sejumlah proses perhitungan selama proses pembelajaran [2].

Jaringan Syaraf Tiruan dapat menunjukkan sejumlah karakteristik yang dimiliki oleh otak manusia, diantaranya adalah:

1. Kemampuan untuk belajar dari pengalaman

2. Kemampuan untuk melakukan generalisasi terhadap masukan baru dari pengetahuan yang dimilki.

3. Kemampuan mengabstraksikan karakteristik penting dari masukan yang mengandung data yang tidak penting.

Seperti halnya otak manusa, jaringan syaraf juga terdiri dari beberapa neuron, neuron-neuron tersebut akan mentransformasikan informasi yang diterima melalui sambungan keluarnya menuju ke neuron-neuron yang lain. Pada jaringan syaraf, hubungan ini dikenal dengan dengan nama bobot. Dalam nilai bobot itulah jaringan syaraf tiruan menyimpan ilmu pengetahuannya. 


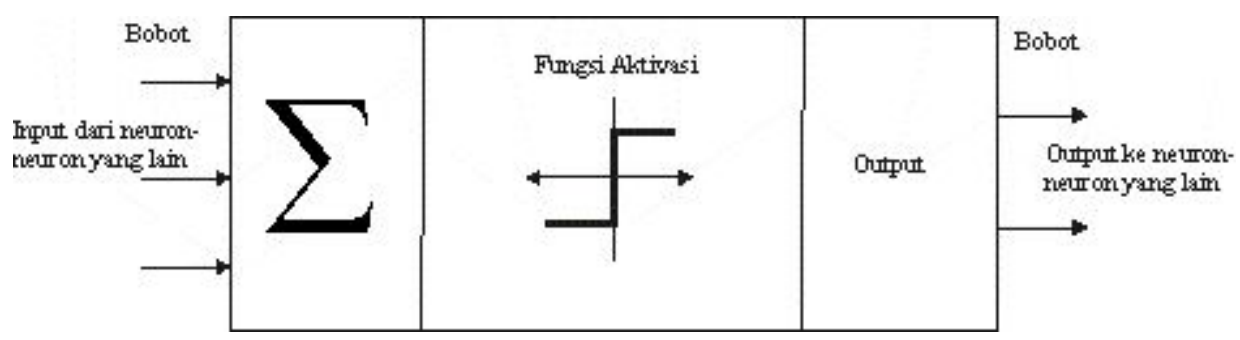

Gambar 2. Struktur Neuron Jaringan Syaraf Tiruan

\subsubsection{Algoritma Back-Propagation}

Back-propagation merupakan algoritma pembelajaran yang terawasi dan biasanya digunakan oleh perceptron dengan banyak lapisan untuk mengubah bobot-bobot yang terhubung dengan neuron-neuron yang ada pada lapisan tersembunyinya. Algoritma back-propagation menggunakan error output untuk mengubah nilai bobot-bobotnya dalam arah mundur (backward). Untuk mendapatkan error ini, tahap perambatan maju (forward propagation) harus dikerjakan terlebih dahulu. Pada saat perambatan maju, neuron-neuron diaktifkan dengan menggunakan fungsi aktivasi sigmoid.

\subsubsection{Pengembangan Algoritma}

Pada fungsi pelatihan sederhana back-propagation dapat dilatih dengan menggunakan fungsi pelatihan trainbp. Metode pelatihan ini merupakan metode pelatihan yang terlalu sederhana dan sangat lambat karena hanya menggunakan konstanta pembelajaran yang konstan. Untuk lebih mempercepat proses pelatihan, algoritma pelatihan selanjutnya diperbaiki dengan pengembangan algoritma dengan menambah momentum dan adaptive learning rate yaitu dengan fungsi pelatihan traingdx.

\section{METODOLOGI}

\subsection{Obyek dan Subyek Penelitian}

Penelitian dilakukan di Usaha Kecil Menengah (UKM) binaan Kadinda Kabupaten Pasuruan Jawa Timur, adapun obyek yang yang diteliti adalah Setir Mobil (steering wheel). Dalam penelitian ini observasi dilakukan dengan menggunakan daftar pertanyaan atau kuesioner. Pengambilan sampel responden dilakukan terhadap konsumen pemakai (pelanggan) dengan sifat acak atau random.

\subsection{Prosedur Kansei Engineering}

Dalam Kansei Engineering System tersusun atas 3 subsistem antara lain: Kansei Analysis, Kansei Inference, dan Kansei Presentation. Gambar 3.1 dapat menjelaskan 3 subsistem di atas [4].

Subsistem pertama adalah mengumpulkan kata-kata kansei yang sesuai dengan produk. Semantic Differentials (SD) Evaluation I digunakan untuk 
menangkap kansei (perasaan atau citra) pelanggan terhadap produk ke dalam data numeris. Untuk memudahkan desainer dalam menangkap preferensi yang diberikan oleh pelanggan melalui kata-kata kansei tersebut, analisis faktor digunakan untuk mereduksi kata-kata kansei (variabel manifes) menjadi jumlah yang lebih sedikit (variabel laten) dengan memanfaatkan hubungan antar variabel.

SD Evaluation II diigunakan untuk memberikan penilaian antara item dan kategori desain dikaitkan dengan kata-kata kansei. Data penilaian tersebut kemudian dianalisis dengan manggunakan Conjoint Analysis untuk mencari hubungan antara kata kansei dengan item dan ketegori elemen desain.

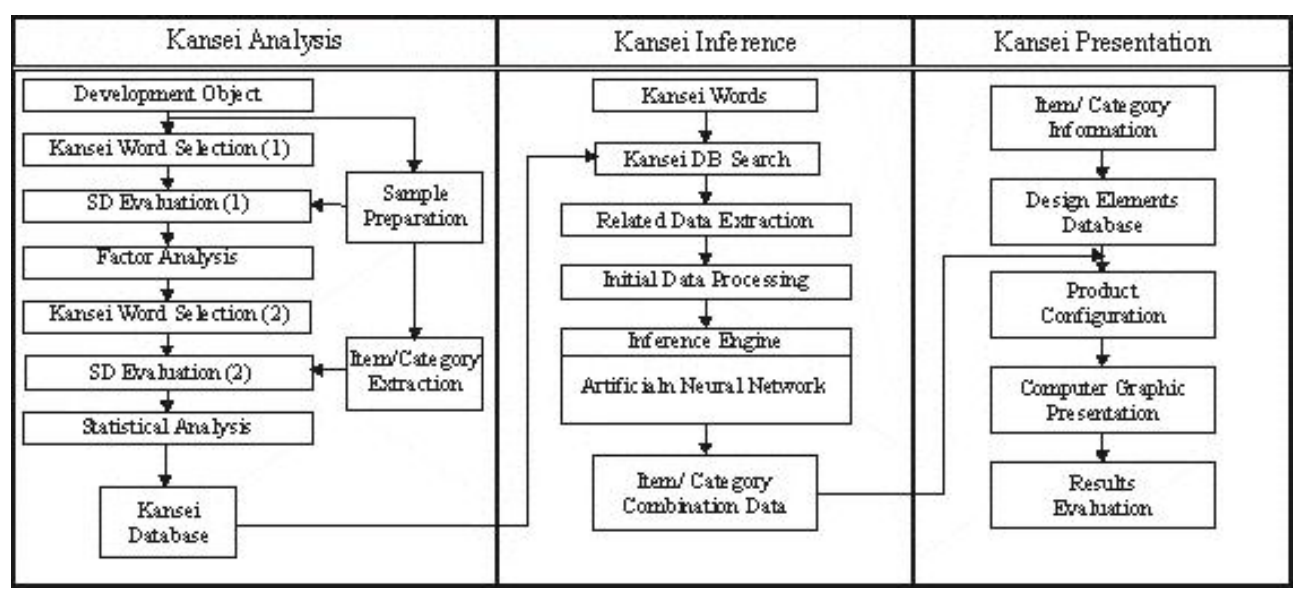

Gambar 3. Arsitektur Kansei Engineering System

Subsistem kedua berfungsi untuk menterjemahkan citra atau perasaan pelanggan kedalam rincian desain yang kongkrit. Disini dapat diterapkan berbagai macam model inferensi seperti teori Fuzzy, Genetic Algorithm, dan kecerdasan buatan lainnya. Dalam penelitian ini digunakan Jaringan Syaraf Tiruan model Back-Propagation dengan fungsi pelatihan Traingdx.

Berkaitan dengan subsistem ketiga semua rincian desain yang terdiri dari aspek-aspek komponen desain yang berkolerasi dengan hasil inferensi pada subsistem kedua dapat ditayangkan dalam bentuk grafis pada layar.

\section{HASIL DAN PEMBAHASAN}

\subsection{Pengumpulan Data}

\subsubsection{Sampel Produk (Steering Wheel) yang mewakili pasar}

Pada tahap ini yang dilakukan adalah mencari bentuk dari setir mobil (steering wheel) yang ada di pasaran. Sampel produk diambil dari UKM Binaan Kadinda Kabupaten Pasuruan Jawa Timur. Bentuk yang digunakan adalah sebanyak 25 jenis. 


\subsubsection{Kata-Kata Kansei}

Diperoleh dari hasil survey yang dilakukan pada konsumen pemakai atau pelanggan. Adapun kata-kata kansei yang diambil sebanyak 17 pasang, seperti ditunjukkan pada Tabel 1.

Tabel 1. Pasangan kata kansei untuk penelitian

\begin{tabular}{|c|c|}
\hline$\left(\mathrm{X}_{1}\right)$ & Polos (colorless)_Penuh Warna (colorful) \\
\hline$\left(X_{2}\right)$ & Sederhana (plain)_Mewah (luxurious) \\
\hline$\left(X_{3}\right)$ & Ramping (slim)_Kekar (muscular) \\
\hline$\left(\mathrm{X}_{4}\right)$ & Modern (modern)_Klasik (classic) \\
\hline$\left(X_{5}\right)$ & Kasar (rough)_Halus (fine) \\
\hline$\left(\mathrm{X}_{6}\right)$ & Biasa (ordinary)_Sporty (sporty) \\
\hline$\left(X_{7}\right)$ & Umum (common)_Unik (unique) \\
\hline$\left(\mathrm{X}_{8}\right)$ & Feminin (feminine)_Maskulin (masculine) \\
\hline$\left(X_{9}\right)$ & Kacau (vulgar)_Rapi (elegant) \\
\hline$\left(\mathrm{X}_{10}\right)$ & Seragam (uniform)_Bervariasi (various) \\
\hline$\left(X_{11}\right)$ & Tidak Artistik (inartistic)_Artistik (artistic) \\
\hline$\left(X_{12}\right)$ & Pudar (dull)_Mengkilap (glossy) \\
\hline$\left(X_{13}\right)$ & Kuno (old-fashioned)_Futuristik(futuristic) \\
\hline$\left(X_{14}\right)$ & Lemah (weak)_Kuat (strong) \\
\hline$\left(X_{15}\right)$ & Simpel (simple)_Komplek (complex) \\
\hline$\left(X_{16}\right)$ & Gelap (dark)_Terang (bright) \\
\hline$\left(\mathrm{X}_{17}\right)$ & Membosankan (boring)_Menarik (interesting) \\
\hline
\end{tabular}

\subsubsection{Penilaian Konsumen terhadap Kata Kansei}

Setelah mendapat kata-kata kansei, kemudian dilakukan penilaian mengenai kriteria setir mobil yang diinginkan dengan memberikan penilaian pasangan kata kansei dengan teknik Semantic Differential (SD Evaluation I).

\subsubsection{Penilaian Kata Kansei untuk Item Kategori Elemen Desain}

Pada kuesioner Semantic Differential (SD Evaluation II) ini, responden diminta kembali membarikan penilaian untuk tiap-tiap sampel produk dikaitkan dengan kata kansei yang tersedia.

\subsubsection{Data Antropometri}

Data antropometri yang diperoleh adalah data antropometri statis, yaitu data antropometri dimana pengukuran dilakukan pada tubuh manusia yang berada dalam posisi diam. Data tersebut antara lain: lebar telapak tangan metakarpal (LTT), lebar telapak tangan sampai ibu jari (LTTI), lebar ibu jari (LIJ), panjang ibu jari (PIJ), lebar jari tengah (LIJ), diameter genggaman maximum (DG) dan lebar segi empat minimum yang dapat dilewati tangan (SEM). Data antropometri yang diperoleh harus memenuhi uji keseragaman dan kecukupan data. 


\subsection{Pembahasan}

\subsubsection{Seleksi Kata Kansei I}

\section{a. Uji Validitas}

Uji validitas digunakan untuk mengukur sah atau tidaknya suatu kuesioner. Suatu kuesioner dikatakan valid jika pertanyaan pada kuesioner mampu untuk mengungkapkan sesuatu yang akan diukur oleh kesioner tersebut. Dari hasil uji validitas diketahui bahwa untuk variabel $\left(\mathrm{X}_{8}\right)$ feminin (feminine)-maskulin (masculine) dikatakan tidak valid karena mempunyai nilai $r$ hitung yang lebih kecil dari $r$ tabel $(0.0415<0.1668)$. Selanjutnya variabel tersebut dikeluarkan dan tidak digunakan dalam analisis selanjutnya.

\section{b. Uji Reliabilitas}

Suatu kuesioner bisa dikatakan reliabel (handal) jika jawaban seseorang terhadap pertanyaan adalah konsisten atau stabil dari waktu ke waktu. Dari uji reliabilitas yang dilakukan terhadap 16 pasangan kata kansei yang telah dinyatakan valid diperoleh nilai Alpha Cronbach hitung yang positif dan lebih besar dari nilai $\mathrm{r}$ tabel $(0.9160>0.1668)$ sehingga dapat dikatakan bahwa butir-butir kuesioner adalah reliabel.

\section{c. Analisis Faktor}

Analisis faktor merupakan salah satu prosedur reduksi data dalam teknik statistik multivariat. Dengan memanfaatkan hubungan (korelasi) antar variabel akan dipergunakan untuk membentuk variabel baru (variabel laten) yang jumlahnya lebih sedikit daripada variabel awal (variabel manifes). Dalam Konsep Kansei Engineering System hasil analisis faktor ini akan menyarankan (memfokuskan) ruang tujuan dalam menentukan item dan kategori desain produk berdasarkan citra atau perasaan pelanggan dalam kata kansei.

Dari hasil analisis faktor ini diketahui konsumen dalam memilih produk setir mobil berdasarkan perasaan atau citra terhadap produk, dipengaruhi oleh 5 faktor yang menjelaskan variansi total sebesar sebesar $82.103 \%$, dengan perinciannya adalah: faktor estetika dengan variansi sebesar $45.523 \%$, faktor evaluasi emosional dengan variansi sebesar $12.255 \%$, faktor warna dengan variansi sebesar $9.810 \%$, faktor texture bahan dengan variansi sebesar $8.079 \%$, dan faktor reliability dengan variansi sebesar $6.435 \%$. Hasil dari analisis faktor selengkapnya dapat dilihat dalam Tabel 2. 
Tabel 2. Hasil analisis faktor

\begin{tabular}{|c|c|c|c|c|}
\hline Faktor & Variabel & Bobot & $\begin{array}{l}\text { Pasangan kata kansei } \\
\text { Yang membentuk faktor }\end{array}$ & Nama faktor \\
\hline \multirow{5}{*}{1} & $\mathrm{X}_{4}$ & 0.789 & Moderen(modern)-Klasik (classic) & \multirow{5}{*}{$\begin{array}{c}\text { Aesthetic } \\
\text { characteristic }\end{array}$} \\
\hline & $\mathrm{X}_{6}$ & 0.889 & Biasa(ordinary)-Sporty(sporty) & \\
\hline & $X_{11}$ & 0.781 & Tdk. Artistik(inartistic)-Artistik(artistic) & \\
\hline & $\mathrm{X}_{13}$ & 0.843 & Kuno(old-fashioned)-Futuristik(futuristic) & \\
\hline & $\mathrm{X}_{15}$ & 0.787 & Simpel(simple)-Komplek(complex) & \\
\hline \multirow{4}{*}{2} & $X_{2}$ & 0.808 & Sederhana(plain)-Mewah(luxurious) & \multirow{4}{*}{$\begin{array}{l}\text { Emotiaonal } \\
\text { evaluation }\end{array}$} \\
\hline & $\mathrm{X}_{7}$ & 0.834 & Umum(common)-Unik(unique) & \\
\hline & $\mathrm{X}_{9}$ & 0.834 & Kacau(vulgar)-Rapi(elegant) & \\
\hline & $\mathrm{X}_{17}$ & 0.822 & Membosankan(boring)-Menarik(intersting) & \\
\hline \multirow{3}{*}{3} & $\mathrm{X}_{1}$ & 0.884 & Polos(colorless)-Warna(colorful) & \multirow{3}{*}{ Color } \\
\hline & $X_{12}$ & 0.855 & Pudar(dull)-Tajam(sharp) & \\
\hline & $X_{16}$ & 0.779 & Gelap(dark)-Terang(bright) & \\
\hline \multirow{2}{*}{4} & $\mathrm{X}_{5}$ & 0.866 & Kasar(rough)-Halus(fine) & \multirow{2}{*}{ Texture } \\
\hline & $\mathrm{X}_{10}$ & 0.924 & Seragam(uniform)-Bervariasi(various) & \\
\hline \multirow{2}{*}{5} & $X_{3}$ & 0.765 & Ramping(slim)-Kekar(muscular) & \multirow{2}{*}{ Reliability } \\
\hline & $X_{14}$ & 0.872 & Lemah(mild)-Kuat(strong) & \\
\hline
\end{tabular}

\subsubsection{Seleksi Kata Kansei II}

a. Item dan Kategori Elemen Desain

Item dan kategori elemen desain produk setir mobil ditunjukkan pada Tabel 3.

Tabel 3. Item dan kategori elemen desain produk setir mobil

\begin{tabular}{|c|c|}
\hline Design Item & Level/ Ketegori \\
\hline A. Bentuk Kenop (shape of button) & $\begin{array}{l}\text { a1. Lingkaran (circle) } \\
\text { a2. Bersiku (angular) } \\
\text { a3. Kurva (curve) }\end{array}$ \\
\hline B. Jumlah Jari-Jari (number of spokes) & $\begin{array}{l}\text { b1. Dua Batang (2 spokes) } \\
\text { b2. Tiga Batang ( } 3 \text { spokes) } \\
\text { b3. Empat Batang (4 spokes) }\end{array}$ \\
\hline C. Material Jari-Jari (material of spokes) & $\begin{array}{l}\text { c1. Baja Tahan Karat (stainless steel) } \\
\text { c2. Alumunium (aluminum) } \\
\text { c3. Kover Kulit (covered in leather) }\end{array}$ \\
\hline D. Tekstur Genggaman (texture of grip) & $\begin{array}{l}\text { d1. Kulit (leather) } \\
\text { d2. Busa (foam) } \\
\text { d3. Kayu (wood) } \\
\text { d4. Plastik Urethane (urethane plastics) }\end{array}$ \\
\hline E. Tambahan Gaya (style of grip) & $\begin{array}{l}\text { e1. Genggaman Tangan (hand grip) } \\
\text { e2. Jari Tangan (finger grip) } \\
\text { e3. Tidak Ada (none) }\end{array}$ \\
\hline F. Warna (color) & $\begin{array}{l}\text { f1. Hitam (black) } \\
\text { f2. Coklat (brown) } \\
\text { f3. Abu-Abu (gray) } \\
\text { f4. Merah (red) } \\
\text { f5. Biru (blue) }\end{array}$ \\
\hline
\end{tabular}




\section{b. Conjoint Analysis}

Hasil dari Conjoint Analysis dapat diketahui hubungan antara kata kansei dengan item dan kategori elemen desain melalui nilai utility.

Negatif (-)

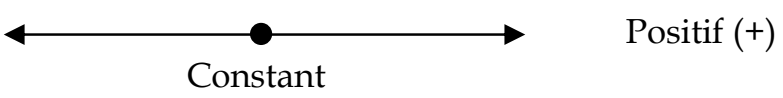

Nilai negatif berarti kategori desain sesuai dengan lawan kata kansei dan tidak sesuai dengan dengan kata kansei, sedangkan nilai positif berarti kategori desain sesuai dengan kata kansei dan tidak sesuai dengan lawan kata kansei. Sehingga untuk setiap pasangan kata kansei (j-k) berlaku:

$$
x_{j k}^{\lambda}= \begin{cases}1 & \text { Dimana kategori desain }(\lambda) \text { sesuai dengan lawan kata kansei }(\mathrm{j}) \\ 0 & \text { Dimana kategori desain }(\lambda) \text { sesuai dengan kata kansei }(\mathrm{k})\end{cases}
$$

Dengan menggunakan persamaan di atas hasil Analysis Conjoint dikonversi dalam notasi angka 0 dan 1 sebagai input Jaringan Syaraf Tiruan (Tabel 4)s.

Tabel 4. Input jaringan syaraf tiruan untuk responden I

\begin{tabular}{|c|c|c|c|c|c|c|c|c|c|c|c|c|c|c|c|c|}
\hline \multicolumn{10}{|c|}{ Kansei word: Modern (modern) - Klasik (classic) } \\
\hline & $\mathbf{X}_{\mathbf{4}}$ & $\mathbf{X}_{\mathbf{6}}$ & $\mathbf{X}_{\mathbf{1 1}}$ & $\mathbf{X}_{\mathbf{1 3}}$ & $\mathbf{X}_{\mathbf{1 5}}$ & $\mathbf{X}_{\mathbf{2}}$ & $\mathbf{X}_{\mathbf{7}}$ & $\mathbf{X}_{\mathbf{9}}$ & $\mathbf{X}_{\mathbf{1 7}}$ & $\mathbf{X}_{\mathbf{1}}$ & $\mathbf{X}_{\mathbf{1 2}}$ & $\mathbf{X}_{\mathbf{1 6}}$ & $\mathbf{X}_{\mathbf{5}}$ & $\mathbf{X}_{\mathbf{1 0}}$ & $\mathbf{X}_{\mathbf{3}}$ & $\mathbf{X}_{\mathbf{1 4}}$ \\
\hline a1 & 1 & 1 & 1 & 1 & 1 & 1 & 1 & 0 & 1 & 1 & 1 & 1 & 1 & 1 & 0 & 1 \\
\hline $\mathbf{a 2}$ & 0 & 1 & 1 & 0 & 0 & 0 & 1 & 0 & 0 & 0 & 0 & 1 & 0 & 0 & 0 & 0 \\
\hline a3 & 0 & 0 & 0 & 0 & 0 & 0 & 0 & 1 & 0 & 0 & 0 & 0 & 1 & 0 & 1 & 1 \\
\hline $\mathbf{b 1}$ & 1 & 0 & 1 & 0 & 0 & 0 & 1 & 0 & 0 & 0 & 0 & 0 & 0 & 1 & 0 & 0 \\
\hline b2 & 0 & 1 & 0 & 1 & 1 & 1 & 0 & 1 & 1 & 1 & 1 & 1 & 1 & 1 & 1 & 1 \\
\hline b3 & 0 & 0 & 0 & 1 & 0 & 1 & 0 & 1 & 0 & 0 & 0 & 1 & 1 & 0 & 1 & 0 \\
\hline c1 & 1 & 0 & 1 & 0 & 1 & 0 & 1 & 0 & 1 & 1 & 1 & 1 & 0 & 1 & 0 & 0 \\
\hline c2 & 0 & 1 & 1 & 1 & 1 & 1 & 0 & 0 & 1 & 1 & 1 & 1 & 1 & 1 & 1 & 1 \\
\hline c3 & 0 & 0 & 0 & 0 & 0 & 0 & 0 & 1 & 0 & 0 & 0 & 0 & 1 & 0 & 1 & 1 \\
\hline d1 & 0 & 1 & 0 & 1 & 1 & 1 & 0 & 1 & 1 & 0 & 0 & 0 & 1 & 0 & 1 & 1 \\
\hline d2 & 1 & 1 & 0 & 1 & 1 & 1 & 1 & 0 & 0 & 1 & 0 & 0 & 0 & 1 & 0 & 1 \\
\hline d3 & 1 & 0 & 0 & 0 & 0 & 0 & 0 & 0 & 0 & 0 & 0 & 0 & 0 & 0 & 0 & 0 \\
\hline d4 & 1 & 0 & 1 & 0 & 0 & 0 & 1 & 0 & 1 & 1 & 1 & 1 & 1 & 1 & 0 & 0 \\
\hline e1 & 0 & 1 & 1 & 1 & 1 & 1 & 0 & 1 & 1 & 1 & 1 & 1 & 1 & 1 & 1 & 1 \\
\hline e2 & 1 & 0 & 1 & 0 & 1 & 0 & 1 & 0 & 0 & 0 & 0 & 0 & 0 & 0 & 0 & 0 \\
\hline e3 & 1 & 0 & 0 & 0 & 0 & 0 & 0 & 0 & 0 & 1 & 1 & 1 & 1 & 0 & 0 & 0 \\
\hline $\mathbf{f 1}$ & 0 & 1 & 0 & 1 & 1 & 1 & 0 & 0 & 1 & 0 & 0 & 0 & 0 & 0 & 1 & 1 \\
\hline $\mathbf{f 2}$ & 1 & 0 & 0 & 0 & 0 & 0 & 0 & 0 & 0 & 1 & 1 & 1 & 1 & 0 & 0 & 0 \\
\hline f3 & 0 & 1 & 1 & 1 & 1 & 1 & 1 & 0 & 0 & 0 & 0 & 0 & 0 & 0 & 0 & 1 \\
\hline $\mathbf{f 4}$ & 0 & 1 & 1 & 1 & 1 & 1 & 1 & 1 & 1 & 1 & 1 & 1 & 1 & 1 & 1 & 1 \\
\hline f5 & 1 & 1 & 0 & 0 & 0 & 0 & 1 & 1 & 1 & 1 & 1 & 1 & 1 & 1 & 0 & 1 \\
\hline
\end{tabular}


Untuk pasangan kata kansei yang lain digunakan cara yang sama, sehingga setiap pola masukan JST berisi 16 neuron yang merupakan representasi dari hubungan tiap-tiap pasangan kata kansei dengan kategori elemen produk.

\subsubsection{Implementasi Jaringan Syaraf Tiruan}

Mengacu pada sifat pemetaan oleh JST, maka JST Perambatan Balik yang digunakan memiliki 3 lapis, yaitu: 1 lapisan masukan, 1 lapisan tersembunyi (hidden layer) dan 1 lapisan keluaran. Lapisan masukan terdiri dari 16 sel yang merupakan banyaknya variabel masukan jaringan, sedangkan lapisan keluaran terdiri dari 1 sel yang merupakan target keluaran jaringan. Jumlah sel lapisan tersembunyi ditentukan oleh (the number of input nods + the number of output nods) $/ 2$ [1]; $(16+1) / 2=8.5 ; \ddot{U} 9$ sel pada hidden layer. Konfigurasi lengkap dari jaringan yang digunakan adalah sebagai berikut:

$\begin{array}{lll}\text { 1. Jaringan syaraf: } & \text { Back-Propagation } \\ \text { 2. Jumlah sel pada lapisan masukan: } & 16 \text { buah } \\ \text { 3. Jumlah sel pada lapisan tersembunyi: } 9 \text { buah } \\ \text { 4. Jumlah sel pada lapisan keluaran: } & 1 \text { buah } \\ \text { 5. Galat: } & 1 \mathrm{e}-3 \\ \text { 6. } & \text { Learning rate awal: } & 0.1 \\ \text { 7. } & \text { Kenaikan laju belajar: } & 1.2 \\ \text { 8. Penurunan laju belajar: } & 0.6 \\ \text { 9. Maksimum epoch: } & 10000 \\ \text { 10. Momentum: } & 0.75 \\ \text { 11. Sedang epoch show: } & 100 \\ \text { 12. Fungsi aktivasi: } & \operatorname{logsig}\end{array}$

Suatu karakteristik dari JST adalah kemampuannya untuk belajar seperti otak manusia, pelatihan yang diberikan padanya menunjukkan kesamaan dengan perkembangan intelektual manusia. Pelatihan bertujuan untuk melihat kinerja jaringan dan ketepatan jaringan pada periode pelatihan (epoch) tertentu. Dengan metode pelatihan traingdx diketahui, untuk mencapai konvergensi dalam mengidentifikasi pola desain produk, jaringan memerlukan: 186 epoch untuk bentuk tombol kenop (shape of button), 56 epoch untuk jumlah jari-jari kemudi (number of spokes), 87 epoch untuk material jari-jari (material of spokes), 488 epoch untuk tekstur genggaman (texture of grip), 172 epoch untuk gaya (style of grip), dan 501 epoch untuk warna (color).

Setelah sistem belajar dengan data base yang telah ada, kita dapat memasukkan pola baru dengan parameter variabel yang sama tetapi dengan pola yang berbeda. Pola yang telah dipelajari oleh sistem dapat digunakan untuk menterjemahkan preferensi baru yang diberikan. Contoh preferensi baru yang diberikan adalah pada Tabel 5 . 
Tabel 5. Preferensi Responden Baru

\begin{tabular}{|c|c|c|c|c|c|c|c|c|c|c|c|c|c|c|c|}
\hline \multicolumn{1}{|l|}{ Pola masukan JST } \\
\hline $\mathbf{X}_{\mathbf{4}}$ & $\mathbf{X}_{\mathbf{6}}$ & $\mathbf{X}_{\mathbf{1 1}}$ & $\mathbf{X}_{\mathbf{1 3}}$ & $\mathbf{X}_{\mathbf{1 5}}$ & $\mathbf{X}_{\mathbf{2}}$ & $\mathbf{X}_{\mathbf{7}}$ & $\mathbf{X}_{\mathbf{9}}$ & $\mathbf{X}_{\mathbf{1 7}}$ & $\mathbf{X}_{\mathbf{1}}$ & $\mathbf{X}_{\mathbf{1 2}}$ & $\mathbf{X}_{\mathbf{1 6}}$ & $\mathbf{X}_{\mathbf{5}}$ & $\mathbf{X}_{\mathbf{1 0}}$ & $\mathbf{X}_{\mathbf{3}}$ & $\mathbf{X}_{\mathbf{1 4}}$ \\
\hline 1 & 1 & 1 & 1 & 0 & 0 & 1 & 1 & 1 & 1 & 1 & 1 & 1 & 1 & 0 & 1 \\
\hline Hasil output JST & & \\
\hline
\end{tabular}

\section{SIMPULAN DAN SARAN}

\subsection{Simpulan}

Dari analisis dan pembahasan dapat disimpulkan hal-hal sebagai berikut:

a. Konsumen dalam memilih produk setir mobil berdasarkan preferensi (perasaan dan citra) terhadap produk, dipengaruhi oleh 5 faktor antara lain: faktor estetika, faktor emosional, faktor warna, faktor texture, faktor reliability.

b. Jaringan Syaraf Tiruan model Backpropagation dengan metode pelatihan Traingdx digunakan sebagai inference engine dalam mengidentifikasi pola desain produk yang terdiri dari: bentuk tombol kenop (shape of button), jumlah jari-jari kemudi (number of spokes), material jari-jari (material of spokes), tekstur genggaman (texture of grip), gaya (style of grip), warna (color).

c. Setelah Jaringan Syaraf Tiruan dilatih dengan pola yang tersedia, jaringan selanjutnya dapat digunakan untuk mengidentifikasi pola masukan baru dengan parameter variabel yang sama tetapi dengan pola yang berbeda.

\subsection{Saran}

Beberapa saran yang dapat diusulkan adalah:

a. Sebagai metode dalam perancangan produk baru Kansei Engineering System dapat diterapkan secara luas dalam berbagai bidang.

b. Selain menggunakan Jaringan Syaraf Tiruan, untuk penelitian lebih lanjut diharapkan dapat diaplikasikan kecerdasan buatan (artificial intelligence) lainnya dalam Kansei Engineering System.

\section{PUSTAKA}

[1] Cheng-Lin, Y., dan Lai, H-H. (2001) Design Optimation of Product Forms Using Neural Networks: A Case Study of Celluler Phones, National Cheng-Kung University, Taiwan.

[2] Kusumadewi, S. (2003) Artificial Intelligence: Teknik dan Aplikasinya, Graha Ilmu, Jogjakarta.

[3] Nagamachi, M. (1995) Kansei Engineering: A New Ergonomic ConsumerOriented Technology for Product Development, International Journal of Industrial Ergonomics 15, Elsevier, Japan: 3-11. 
[4] Nagamachi, M., Lee, S., dan Yang, S. (1999) Rule-Based Inference Model for the Kansei Engineering System, International Journal of Industrial Ergonomics 19, Elseiver: Japan: 459-471.

[5] Nurmianto, E. (1996) Ergonomi, Konsep Dasar dan Aplikasinya, Edisi Pertama, PT. Guna Widya, Jakarta.

[6] Sutalaksana, I.Z. (1999) Produk-Produk Ergonomis dan Strategi Mewujudkannya, Proceeding Simposium dan Pameran Ergonomi Indonesia 2000, Tehnology Business Operation Unit IPTN, Bandung: I: 19-24.

[7] Tarwaka, Bakri, S.H.A., dan Sudiajeng, L. (2004) Ergonomi untuk Kesehatan, Keselamatan Kerja dan Produktivitas, Uniba Press, Surakarta.

[8] Wignjosoebroto, S. (1995) Ergonomi Studi Gerak dan Waktu, PT. Candimas Metropole, Jakarta. 